\title{
NEGOSIASI IDENTITAS MASYARAKAT ADAT AMMATOA TERHADAP SISTEM PENDIDIKAN MODERN
}

\author{
Ayu Adriyani (1), Partini (2), Muhammad Sulhan (3) \\ Penyuluhan \& Komunikasi Pembangunan, Sekolah Pascasarjana, Universitas Gadjah Mada (l) \\ Sosiologi, Fakultas Ilmu Sosial dan Ilmu Politik, Universitas Gadjah Mada(2) \\ Ilmu Komunikasi, Fakultas Ilmu Sosial dan Ilmu Politik, Universitas Gadjah Mada ${ }^{(3)}$ \\ e-mail:ayu.adriyani@mail.ugm.ac.id
}

\begin{abstract}
Ammatoan is one of the Indegenous people in Indonesia who still hold their traditional wisdom to ensure that their customary land and traditions must be sustain. Ammatoan led by the Ammatoa. Ammatoa is the name for anyone who mandatory as a leader of the Ammatoan. The interesting fact is the Ammatoan has a long history as a traditional community with a strong oral culture. The other fact is the Ammatoan should face the modern education with a strong literacy culture. The Elementary School building has been built only about several meters from the gate that sepearated the ilalang embayya dan ipantarang embayya. The Ammatoan are still living in a diversity of their tradition. The Ammatoan who are living in the Ilalang Embayya has been practiced the adat fully. It makes the Ammatoan are very selective with the modernitation. But the Ammatoan who are living in Ipantarang embayya has receieved it as like as the society generally. The existence of formal education facilities in Ammatoan's village should be made them negotiate to make sure that the adat and their tradition are sustain. This study ia a qualitative by using a quick etnoghraphhy (Observation of partitipation and life story interview) to see the deep life of indigeneous people of Ammatoa. The aim of this study is to see how is the identity negotiation of The Ammtoan to feca the modern education. As a result, their decision to open their community to the modern education was the part of their political strategy. They did it because it related to their existence for the future.
\end{abstract}

Keywords - Indigeneous people, Ammatoan, local wisdom, education

\begin{abstract}
ABSTRAK
Masyarakat Adat Ammatoa adalah salah satu masyarakat yang masih memegang teguh kearifan tradisional untuk memastikan agar tanah adat dan tradisi mereka tetap lestari. Masyarakat adat Ammatoa dipimpin secara adat oleh seorang Ammatoa. Ammatoa adalah sebutan untuk siapa saja yang menjabat sebagai pemimpin adat. Namun, masyarakat adat Ammatoa yang masih mewarisi tradisi lisan dari leluhur mereka harus berhadapan dengan pendidikan modern yang lebih kuat dengan tradisi tulis. Satu bangunan SD telah didirikan beberapa meter dari gerbang pembatas antara ilalang embayya dan ipantarang embayya. Masyarakat adat Ammatoa masih hidup dengan keragaman tradisi mereka. Masyarakat ilalang embayya adalah masyarakat yang masih menjalankan adat secara penuh sehingga sangat selektif terhadap kemajuan zaman, namun masyarakat di ipantarang embayyasudah lebih terbuka. Dengan keberadaan sarana pendidikan formal di desa mereka, menyebabkan masyarakat Adata Ammatoa pun harus bernegosiasi untuk memastikan agar adat dan tradisi mereka tetap lestari. Penelitian ini adalah penelitian kualitatif dengan menggunakan partisiasi observasi dan life story interview untuk melihat kehidupan masyarakat adat Ammatoa secara lebih mendalam.
\end{abstract}

Penelitian ini dilakukan untuk melihat bagaimana negosiasi identitas masyarakat adat Ammatoa 
terhadap pendidikan modern. Hasilnya, masyarakat adat Ammatoa pada dasanya membuka diri tehadap pendidikan modern. Keputusan mereka menjadi bagian dari strategi politik mereka agar eksistensi mereka tetap bisa diakui.

Kata Kunci: Masyarakat Adat, Ammatoa, kearifan lokal, pendidikan

\section{PENDAHULUAN}

Indonesia dalam keberagaman kultur dan geografisnya masih memiliki banyak masyarakat yang berupaya untuk merawat nilai-nilai lokal mereka. Masyarakat ini berdiam di berbaga daerah. Data Aliansi Masyarakat Adat Nusantara (AMAN) mencatat bahwa Indonesia memiliki kurang lebih 17 juta jiwa masyarakat adat yang berada di bawah naungan sekitar 2.300an komunitas yang tersebar di seluruh Indonesia. Sedangkan data Kementerian Sosial berdasarkan persebaran bantuan untuk Komunitas Adat Terpencil (KAT), mencatat terdapat 1,2 juta jiwa masyarakat Indonesia yang statusnya kemudian disebut sebagai masyarakat adat.

Namun pentingnya kearifan ini tidak hanya untuk memastikan eksistensi komunitas lokal semata. Pandangan dan tindakan arif komunitas lokal terhadap ruang hidupnya adalah modal penting untuk memastikan kelestarian umat manusia pada dasawarsadasawarsa mendatang (Capra, 2017:252). Pada dasarnya, mereka memahami bahwa pengetahuan lokal yang telah terwarisi secara turun temurun adalah untuk memperkuat relasi sosial mereka dengan unsur-unsur alam, seperti tanah, air, udara, dan api. Pandangan ini mengajarkan kesetaraan dalam memposisikan alam sebagai organisme hidup. Sehingga, penghormatan atasnya adalah sebuah keharusan, bukan pilihan.
Semangat ini bisa dilihat dalam mekanisme hidup masyarakat adat Ammatoa yang bermukim di desa Tanah Towa, Kecamatan Kajang Kabupaten Bulukumba, Sulawesi Selatan. Berdasarkan tempat bermukimnya masyarakat adat Ammatoa bermukim di dua tempat. Masyarakat umum sering kali menyebutnya Kajang Dalam dan Kajang Luar. Namun Masyarakat adat Ammatoa lebih sering menyebutnya ilalang embayya dan ipantarang embayya. Ilalang embayya merupakan wilayah adat yang masih sakral, sedangkan ipantarang embayya adalah wilayah yang pola hidup masyarakat yang bermukim di atasnya tidak jauh berbeda dengan masyarakat pada umumnya. Kedua tempat ini mencerminkan keberagaman praktik berpolitik, agama, dan kebudayaan dari masyarakat Adat Ammatoa secara keseluruhan.

Masyarakat adat Ammatoa dipimpin oleh seorang pemimpin adat yang disebut Ammatoa. Ammatoa berasal dari kata Amma (bapak) dan Toa (tua), sehingga Ammatoa berarti bapak yang dituakan. Namun peran dan fungsi Ammatoa memiliki makna yang lebih dalam artinya.

Pemaknaan penting Ammatoa dalam lingkaran masyarakat adat Ammatoa sama pentingnya dengan melihat pasang di dalam lingkaran mereka. Secara harfiah, pasang adalah pesan. Namun dalam pemaknaan yang luas, pasang adalah pedoman hidup 
yang melingkupi masyarakat adat Ammatoa secara keseluruhan. Syarif et al (2016) mengungkapkan bahwa pasang menjadi prinsip legal yang merangkum nilai-nilai lokal masyarakat adat Ammatoa. Melalui penerapan pasang hingga hari ini juga, masyarakat adat Ammatoa mampu memfilter pengaruh dari luar yang masuk ke wilayah mereka (Erawati, 2015: 149).

Mayoritas masyarakat adat Ammatoa bermukim di dalam hutan bersama dengan Ammatoa. Dalam kesehariannya, hutan tidak hanya sebagai ruang untuk menetap namun juga menjadi ruang hidup dan ruang lintas generasi. Ruang hidup, karena seluruh masyarakatnya meletakkan pengharapan akan penghidupan yang senantiasa lebih baik dimulai dari penghargaan terhadap hutan. Sedang ruang lintas generasi, karena melalui hutan inilah, masyarakat Ammatoa memastikan agar kebutuhan generasi hari ini tetap bisa terpenuhi tanpa harus merebut hak anak cucu mereka nantinya. Hutan dalam kepercayaan masyarakat Ammatoa adalah tempat pertama kali diturunkannya leluhur mereka, sehingga merusak hutan berarti sama saja menghilangkan penghormatan terhadap leluhur.

Tidak hanya hutan, masyarakat Ammatoa memahami bahwa penghormatan mereka terhadap alam secara utuh dan sikap kamase-masea (kesederhanaan) yang terus dijaga adalah sarana untuk bisa berkumpul dengan leluhur terdahulu mereka dalam suasana bahagia (Hijjang, 2005:259). Sikap kamase-masea sebagai tendensi keduniaan dari kepercayaan pasang yang diyakini telah terinternalisasi dalam kehidupan masyarakat sehari-hari. Hal ini membuat mereka benarbenar membatasi penggunaan teknologi yang masuk ke dalam kawasan adat (Ilalang embayya). Dalam kesehariannya, penerangan yang digunakan di malam hari hanya bersumber dari kemiri atau getah karet yang diinovasikan bersama kapas dan lidi (Tika et al, 2015:39). Segala kendaraan diparkir di pintu gerbang masuk kawasan, selebihnya orang-orang yang masuk ke kawasan harus berjalan kaki dengan melepas alas kaki. Mayoritas masyarakatnya juga masih menggunakan pakaian berwarna hitam. Warna yang diyakini lekat dengan makna kesederhanaan.

Meski terkesan tertutup, namun sebenarnya mereka masih sangat dinamis dengan budaya sendiri. Sejarah masyarakat adat Ammatoa menunjukkan bahwa hubungannya dengan masyarakat luar telah dijalin, bahkan sejak berabad-abad yang lalu. Hubungan ini terutama dibangun bersama dengan kerajaan besar, seperti Kerajaan Luwu, Gowa, maupun Bone (Hijjang, 2005: 256). Tiga kerajaan yang memiliki peran penting pada zamannya di Sulawesi Selatan.

Intensitas hubungan dengan dunia luar bahkan masih berlangsung hingga hari ini. Arus modernisasi dan pesatnya pembangunan justru membuat interaksi mereka dengan masyarakat luar kawasan semakin meningkat. Salah satu bentuk negosiasi yang akhirnya dilakukan oleh masyarakat Ammatoa terhadap perkembangan zaman adalah satu per satu masyarakat Ammatoa menyekolahkan anaknya ke sekolah formal di 
luar kawasan adat. Saat ini, tercatat terdapat satu TK, tiga SD, satu SMP, dan satu SMA yang letaknya berada di kawasan Desa Tanah Towa. Artinya, berada tidak terlalu jauh dari kawasan adat. Tidak hanya itu, setelah tamat SMA, anak-anak di dalam kawasan Ammatoa juga mendapat kelonggaran untuk melanjutkan ke jenjang pendidikan tinggi.

Dari perspektif pendidikan, hal ini menjadi baik karena proses untuk meningkatkan taraf hidup masyarakat melalui jalur pendidikan bisa diraih. Begitu pula dari perspektif pembangunan yang mengamini hasil cacahan statistik yang konon mengatasi rendahnya kemampuan baca tulis masyarakat Ammatoa dengan mulai membangun fasilitas pendidikan di sekitar kawasan. Namun dari sudut pandang kebudayaan, hal ini menjadi ancaman. Sedikit demi sedikit upaya perlindungan yang masyarakat Ammatoa lakukan terhadap budaya mereka akan mendapat tekanan dari budaya jamak di luar kebiasaan hidup mereka.

Berdasarkan uraian di atas, fakta yang menarik adalah terbukanya masyarakat adat Ammatoa dengan sistem pendidikan modern tidak serta merta membuat perubahan fundamental di dalam tubuh adat dan tradisi mereka. Olehnya, penulis tertarik melihat secara mendalam bagaimana upaya negosiasi yang dilakukan oleh masyarakat adat Ammatoa sejak dulu hingga hari ini sehingga mereka masih bisa bertahan. Penelitian dengan judul "Negosiasi Identitas Masyarakat Adat Ammatoa terhadap Sistem Pendidikan Modern" dalam kerangka kerjanya menjabarkan pertanyaan
"Bagaimana negosiasi identitas masyarakat adat Ammatoa terhadap sistem pendidikan modern?" sebagai rumusan masalah. Sehingga, tujuan dari penelitian ini adalah melihat bagaimana upaya masyarakat adat Ammatoa dalam menegosiasikan budaya mereka ketika diperhadapkan dengan pendidikan modern.

Teori yang digunakan untuk membantu penelitian ini adalah Teori Negosiasi Identitas yang dicetuskan oleh Stella TingToomey. Teori ini mengeksplorasi upaya untuk melihat bagaimana posisi identitas diri di dalam interaksi sosialnya. Identitas diri diperoleh dari situasi yang memungkinkan terjadinya negosiasi seperti mengakui, menyatakan, memodifikasi, atau bahkan mengingkari identifikasi diri pribadi maupun orang lain (Littlejohn dan Foss, 2014:132).

Dalam konteks studi ini, seperti yang juga difokuskan oleh Stella Ting-Toomey, identitas yang dimaksud adalah identitas kebudayaan dan hubungan kebudayaan yang juga penting yaitu identitas etnik. Teori ini menekankan pada upaya untuk melakukan penyeimbangan dengan negosiasi. Ting Toomey menyebut situasi yang memungkinkan orang-orang yang mampu mempertahankan posisi dirinya namun juga mampu masuk ke dalam identitas-identitas yang lain sebagai bikulturalisme fungsional. Situasi ini diraih dalam kemampuan lintas budaya, artinya telah terjadi keseimbangan di dalamnya. Kemampuan lintas budaya ini, terdiri atas tiga komponen, yaitu: Pengetahuan, kesadaran, dan kemampuan.

Pengetahuan yang dimaksud adalah pemahaman terhadap pentingnya identitas 
kebudayaan dan pengidentifikasian perbedaan-perbedaan yang menjadi ciri dari masing-masing etnik ataupun kebudayaan. Komponen kedua yaitu kesadaran, memberikan ruang evaluatif pada diri untuk bersikap pada perspektif-perspektif baru. Sikap ini bisa saja adalah kesediaan untuk membuka diri terhadap perspektif baru. Terakhir adalah kemampuan untuk menegosiasi identitas. Kemampuan ini ditunjukkan dengan melakukan observasi yang mendalam, penghormatan, mengelaborasi, dan perilaku sejenis lainnya. Dalam hal ini negosiasi identitas yang efektif adalah negosiasi yang menghadirkan kesamapahaman, penghormatan, dan penghargaan dari kedua belah pihak (Ibid).

\section{METODE}

Metode yang digunakan di dalam penelitian ini adalah metode observasi partisipasi dan interview secara mendalam. Peneliti tinggal bersama mereka dan ikut serta dalam aktivitas harian, serta ikut berbaur dalam beberapa ritual. Keterlibatan ini membuat peneliti bisa melihat dan mengamati dengan jelas subjek penelitian dalam beberapa aspek. Life Story interview juga digunakan di dalam penelitian ini sebagai alternatif untuk semakin memperdalam metode-metode lainnya.

Pendekatan ini mengambil beberapa orang dalam satu internal kelompok, yang menghimpun reaksi, tanggapan, interpretasi dan penglihatan dari individu-individu diantara mereka mengenai masyarakat yang bersangkutan. Life story mengejar kerangka pengetahuan individu yang juga dilibatkan ke dalam kerangka pengalamannya.

Pendekatan ini dipilih, karena life story memungkinkan orang untuk bercerita jauh lebih banyak tentang kehidupan pribadi atau masyarakatnya. Life story adalah upaya untuk mengungkap keseluruhan pengalaman hidup seseorang, mengingat, atau memilih untuk diingat, tergantung pada kehidupan dan latar belakang hidupnya yang mereka rasa penting untuk diungkapkan dan harus diketahui orang (Atkinson, 1995: 116).

Fokus penelitian ini diturunkan dari pertanyaan penelitian yang telah dirumuskan. Sehingga, konsep utama tentang upaya negosiasi masyarakat adat Ammatoa ketika berhadapan dengan pendidikan modern adalah pegangan dalam penelitian ini. Sedangkan subjek dalam penelitian ini adalah masyarakat adat Ammatoa secara umum, namun untuk menggali lebih dalam maka objek utama adalah mereka yang memiliki pengetahuan dan pengalaman yang berelasi dengan tujuan penelitian ini.

Secara keseluruhan, metode yang digunakan di dalam penelitian ini adalah metode quick etnography (Etnografi Cepat). Penulis tinggal bersama salah satu informan, dan beraktifitas secara intens dengan informan-informan lainnya. Penelitian ini mewawancarai empat orang informan. Life Story interview di dalam penelitian ini, menuntut orang-orang dengan pengetahuan yang mumpuni, namun tidak sekedar tahu, melainkan juga melibatkan pengetahuan mereka ke dalam rangkaian pengalaman mereka. 


\section{HASIL DAN PEMBAHASAN}

Masyarakat adat Ammatoa bermukim di dua tempat ilalang embayya (di dalam batas) dan ipantarang embayya (di luar batas). Wilayah ilalang embayya adalah wilayah sakral yang masih memberlakukan aturan adat secara ketat. Sedangkan, wilayah ipantarang embayya adalah wilayah bebas yang masyarakatnya masih melaksanakan adat, namun tidak penuh.

Hanya saja, pemisahan tempat ini tidaklah berarti. Masyarakat adat Ammatoa adalah masyarakat yang memiliki ikatan personal, tidak peduli dimana ia tinggal. Bagi mereka, ilalang embayya dan ipantarang embayya adalah satu kesatuan secara adat. Ammatoa sebagai pemimpin adat dihormati dan dihargai oleh seluruh masyarakat adat Ammatoa baik yang tinggal di dalam maupun di luar kawasan adat.

Masyarakat adat Ammatoa adalah masyarakat yang kebanyakan proses komunikasinya dilakukan secara lisan. Secara turun temurun, mereka mewarisi tradisi lisan. Hal ini dapat dibuktikan dengan keyakinan kuat mereka terhadap pasang. Pasang secara harfiah berarti pesan. Namun bagi masyarakat adat Ammatoa, pasang menjadi pengetahuan kolektif mereka yang mengatur hubungan horizontal dan vertikal mereka.

Namun di era Orde Baru, hasil cacahan Badan Pusat Statisik (BPS) menggolongkan mereka sebagai masyarakat yang memiliki tingkat pendidikan rendah. Sehingga, pemerintah berinisiatif untuk mendekatkan akses sarana pendidikan. Di tahun 1992, SD 351 sebagai kelas jauh dari SD 115 di Dusun
Balagana di dirikan tepat di dalam kawasan adat (hanya sekitar 200 meter dari batas patok kayu antara ilalang embayya dengan ipantarang embayya.

Hingga hari ini, tercatat terdapat satu buah TK, tiga buah SD, satu buah SMP, dan satu buah SMA di Desa Tanah Towa. Namun yang posisinya paling dekat adalah SD 351. SD 351 adalah sekolah yang khusus dibanguan untuk mendekatkan anak-anak di ilalang embayya dengan akses ke sekolah formal.

\subsection{Tak Apa, Asal Tak Mengganggu Adat}

Melihat pendidikan masyarakat adat Ammatoa tidak bisa sesederhana mendeskripsikan cacahan angka. Ketidakmampuan membaca atau keadaan buta huruf di dalam satu kelompok masyarakat belum cukup bisa diakomodasi oleh satu perspektif tunggal. Freire (2007) menekankan bahwa setidaknya ada dua kondisi yang memungkinkan adanya masyarakat yang buta huruf. Kondisi pertama adalah karena memang mereka tidak butuh untuk membaca dan kondisi yang kedua adalah hak melek huruf mereka yang telah dirampas.

Masyarakat adat Ammatoa tergolong ke dalam kondisi pertama. Mereka adalah masyarakat yang diwarisi budaya lisan oleh leluhur mereka. Sehingga, mereka tumbuh dengan dominasi budaya lisan dalam keseharian mereka. Meskipun mereka tidak lagi mewarisi kelisanan primer secara ketat, namun dalam tingkatan yang masih cukup kuat, mereka masih berusaha mempertahankan pola pikir kelisanan mereka. Kate- 
gorisasi masyarakat adat Ammatoa ke dalam masyarakat buta huruf dan harus diatasi dengan membuka akses seluas-luasnya adalah cara-cara khas masyarakat aksara yang lebih tepat jika digunakan untuk mengatasi kondisi yang kedua.

Namun bagaimanapun, masyarakat adat Ammatoa tidak memungkiri bahwa mereka ada di dalam pusaran masyarakat aksara. Tentunya, hal ini berada di luar kendali mereka. Upaya yang ditempuh agar tidak tergerus zaman adalah dengan semakin selektif terhadap hal-hal baru di sekitar mereka. Keberadaan sekolah-sekolah formal dan anak-anak mereka yang pada akhirnya disekolahkan ke sana menjadi salah satu alasannya. Bagaimanapun, sekolah-sekolah formal adalah ruang yang dikembangkan dengan budaya tulis.

"Tidak apa-apa kalau orang di sini sekolah. Yang penting, dia pintar memisahkan, aturan pemerintah dengan aturan di dalam adat. Jangan menggurui tanah kelahiranmu. Justru itu namanya membodoh-bodohi. Tugasmu adalah menjaga tanah kelahiranmu" (Wawancara dengan $A B$ )

Pernyataan informan di atas, tidak untuk menegaskan bahwa akan selalu ada kontradiksi antara aturan pemerintah dengan aturan adat. Namun kesadaran bahwa aturan adat yang mereka pegang hingga hari ini memiliki rasionalitas khusus yang terkadang tidak mendapat porsi penuh di dalam rasionalitas Negara itulah yang mereka yakini. Sehingga, mereka membutuhkan kemampuan lebih untuk tetap bisa menjalankan aturan Negara namun tidak merusak adat mereka.
Kemampuan masyarakat Adat Ammatoa mengelaborasi pengetahuan adat mereka dengan sistem Negara adalah bentuk kemampuan lintas budaya yang mereka miliki. Kemampuan ini tidak untuk mengecilkan budaya satu terhadap budaya yang lain, namun untuk semakin menegaskan bahwa keseimbangan hubungan antara keduanya dibutuhkan agar eksistensi mereka tetap terjaga.

Elaborasi ini juga terjadi dalam bidang pendidikan. Prinsip mereka adalah “tidak apa, asal tidak merusak adat". Bagi mereka, tidak ada yang dirubah dalam upaya membuka diri terhadap sistem sekolah formal. Hal yang mereka lakukan adalah "menyisipkan" sistem ini ke dalam kebiasaan sehari-hari mereka. Hal ini yang juga dipahami oleh pihak sekolah (khususnya SD 351) untuk senantiasa berhati-hati di dalam mengeluarkan kebijakan sekolah.

"Kata Amma (Ammatoa), dia lebih
menyetujui saya untukjadi Ketua Komite
di sana. Karena saya pengalaman di
pendidikan. Pengalaman juga di adat.
Jadi mereka tidak lepas"

Kutipan di atas adalah wawancara dengan Galla' Puto. Galla' Puto adalah Juru bicara Ammatoa yang juga adalah Ketua Komite di SD 351. Penunjukan dirinya sebagai Ketua Komite, selain karena salah seorang cucunya yang juga bersekolah di SD 351, Ammatoa lah yang menunjuknya. Pihak sekolah pun terlebih dahulu meminta masukan dari Ammatoa, siapa yang bisa dijadikan sebagai orang yang bisa menjembatani kebutuhan orang tua di dalam 
kawasan dengan hal yang mampu difasilitasi oleh pihak sekolah.

Cara ini juga merupakan bagian dari strategi politik Ammatoa untuk memastikan aturan-aturan sekolah tidak melanggar aturan adat mereka. Meskipun, strategi ini belum pernah digunakan untuk mendiskusikan bersama kurikulum pembelajaran yang seperti apa yang tepat diberikan untuk masyarakat adat. Masyarakat adat Ammatoa menyerahkan sepenuhnya persoalan kurikulum pembelajaran kepada pihak sekolah. Forum-forum sekolah yang dibentuk, pada umumnya membahas tentang hal-hal yang juga bersifat umum, seperti mendiskusikan biaya sekolah, perbaikan sarana dan pra sarana sekolah, dan hal-hal lain yang belum menyentuh substansi budaya masyarakat adat Ammatoa.

Sekolah bagi masyarakat adat Ammatoa di satu sisi memang dipandang membawa kebaikan. Namun di sisi yang lain, mereka memahami bahwa ada adat yang tidak boleh dirubah. Anak-anak yang disekolahkan adalah mereka yang diharapkan justru akan menguatkan posisi adat.

"Orang-orang yang ingin merubah adat adalah orang yang durhaka. Biasanya, perutnya akan dibuat bengkak oleh Tu rie' A'ra'na. Karena dianggap, dia sudah tidak memperhatikan adat. Umurnya akan dipendekkan" (Wawancara dengan AB)

Meski tidak bisa dipungkiri bahwa tantangan orang tua hari ini jauh lebih besar. Jika zaman dulu, orang tua menjadi orang yang paling ditakuti kata-katanya. Namun hari ini, ruang-ruang dialog bersama antara anak dan orang tua itulah yang diciptakan. Waktu yang digunakan biasanya di saat-saat santai, setelah makan, dan sebelum tidur. Orang tua dan anak saling mendengarkan satu sama lain.

Pandangan masyarakat adat Ammatoa yang melihat sekolah sebagai ruang yang justru menguatkan adat tidak lepas dari praktik politik mereka. Mereka memahami bahwa regulasi-regulasi Negara atas tanah dan kebudayaan mereka secara keseluruhan adalah sesuatu yang harus dikawal dengan pengetahuan yang mumpuni. Olehnya, sekolah adalah bagian dari alat perjuangan mereka untuk mendapat pengakuan Negara atas identitas mereka sebagai masyarakat adat. Hal terpeting dari sekolah adalah pengetahuan-pengetahuan kritis yang dapat dirasionalkan ke dalam narasi Negara.

\subsection{Masyarakat Adat Ammatoa dan \\ Kemampuan Lintas Budayanya}

Proses pembelajaran dalam masyarakat adat Ammatoa adalah proses alami yang berlangsung sejak dulu dan hingga hari ini. Ammatoa memahami bahwa proses berpengetahuan untuk menjadi "diri” mereka sebagai masyarakat adat adalah proses pembelajaran yang akan terus berlangsung. Melalui proses pembelajaran, mereka belajar ilmu kehidupan untuk menghidupkan tradisi mereka.

Sesuai dengan aspek yang dibahas oleh Stella Ting-Toomey (Littlejohn \& Foss, 2014:132-134) dalam teori negosiasi identitas, bersifat terbuka namun selektif adalah cara menegosiasikan identitas di 
dalam interaksi dengan kebudayaan yang lain. Identitas masyarakat adat Ammatoa telah terbentuk ketika mereka menyatakan "Tidak apa ada sekolah, asal tidak merusak adat".

Masyarakat adat Ammatoa memahami bahwa mereka punya tanggung jawab yang lebih atas tanah dan tradisi dibandingkan kebudayaan lain di luar mereka. Dalam konteks internal mereka berdaya, namun secara eksternal mereka bisa sangat rentan. Terbukti dengan salah satu konflik yang pernah terjadi antara masyarakat adat Ammatoa dengan salah satu perusahaan karet di Kabupaten Bulukumba yang akhirnya menelan korban jiwa dari kelompok adat. Hal ini berimplikasi pada semakin selektifnya mereka terhadap orang dan kebudayaan baru.

Tanggung jawab lebih atas tanah dan tradisi adalah sesuatu yang tidak sepenuhnya dimiliki oleh rasionalitas Negara. Kesewenang-wenangan pemerintah untuk menyediakan sarana sekolah formal di dalam kawasan adat adalah salah satu bukti kuasa Negara yang tidak mampu menjangkau rasionalitas masyarakat adat saat itu, di zaman orde baru. Ruang mediasi yang dibentuk akhirnya menemukan titik temu. Masyarakat adat Ammatoa di titik yang satu dan pemerintah di titik yang lain. Dua titik ini harus seimbang, jika tidak, maka titik yang lain akan menjadi superior atas titik yang satu dan titik yang satu akan terus tereliminasi oleh zaman.

Keseimbangan ini diperoleh masyarakat adat Ammatoa dengan melakukan upaya negosiasi. Masyarakat adat Ammatoa mampu mempertahankan identitas diri mereka yang kuat, namun juga bisa masuk ke identitas lain secara lebih fleksibel. Sebagian besar masyarakat adat Ammatoa bahkan memiliki kemampuan bikulturalisme fungsional yaitu kemampuan untuk berganti dari satu budaya ke budaya yang lain dengan mudah. Kemampuan ini mengantarkan masyarakat adat Ammatoa mampu masuk menjadi bagian dari budaya lain di luar mereka, tanpa membuat mereka kehilangan esesi kebudayaan menghidupi mereka.

Upaya untuk memperoleh kamampuan tersebut adalah dengan memiliki kemampuan lintas budaya (intercultural competence). Kemampuan ini dapat diperoleh dengan tiga komponen, yaitu pengetahuan (knowledge), kesadaran (mindfulness), dan kemampuan (skill).

Pertama, pengetahuan. Masyarakat adat Ammatoa secara sadar mereka memiliki kepentingan untuk melestarikan adat mereka. Hal ini yang terus mereka lakukan melalui proses pembelajaran dalam kehidupan seharihari. Ilmu kehidupan (Wisdom) adalah yang mereka ajarkan ke anak-anak mereka. Ilmu ini yang mereka gunakan untuk memahami bahwa ritual sesungguhnya adalah sekolah bagi mereka. Melalui sekolah ini, alam menjadi impersonal teacher bagi mereka. Melalui sekolah ini, mereka memaknai hutan sebagai sumber kehidupan.

Hutan menjadi tempat bagi mereka mengasosiasikan hak dan kewajiban mereka terhadap alam secara keseluruhan. Ketika hasil panen mereka tidak begitu bagus, mereka melakukan ritual di dalam hutan. 
Mereka meyakini bahwa segala hal yang buruk yang menimpa mereka (termasuk kurangnya hasil panen) memiliki hubungan dengan kurang berkenannya alam terhadap perilaku mereka. Hal ini sama halnya yang diungkapkan oleh Maarif (2014:152) bahwa hubungan kemanusiaan yang diyakini dalam persepsi masyarakat adat pada umumnya adalah tidak hanya tentang hubungan antar mahluk hidup semata, namun juga pada mahluk seperti binatang, pohon, hutan, kayu, dll.

Pengetahuan-pengteahuan semacam ini yang kurang mampu diakomodir oleh institusi formal, seperti sekolah ala Negara. Jika lingkungan mengajarkan ilmu kehidupan, maka sekolah mengajarakan ilmu pengetahuan. Hal ini dipahami masyarakat adat Ammatoa dengan berharap banyak dari sekolah untuk membantu mereka menghadapi rasionalitas Negara.

"Parallu to'I injo sikolayya. Ka punna taua lalang mae, napertahangkangngi budayya iyya rate ri menteri kebudayaan. Sikolallaya injo pakahajiki. Jari anre'ji nitentangngi. Cuma nipainga'I injo lanju' iyya, pilatterasa 'i. anre'nakkulle nilammai injo ada'a" (Wawancara dengan $A B$ )

"Sekolah juga itu perlu. Karena kalau orang di dalam sini, dia mempertahankan budaya di sini hingga ke Menteri Kebudayaan. Sekolah itu yang membantu. Jadi, kami tidak menentang. Cuman kami mengingatkan, siapapun yang melanjutkan sekolahnya terus, kalau adat itu tidak bisa dilemahkan" (Wawancara dengan AB)

Bagi masyarakat adat Ammatoa, sekolah itu hanyalah salah satu ruang.
Ruang bagi mereka tidak begitu penting, yang terpenting adalah substansi apa yang diberikan ruang belajar bagi mereka agar adat tetap lestari. Dalam menghadapi Negara, mereka memahami ilmu kehidupan mereka membutuhkan sokongan ilmu pengetahuan yang difasilitasi oleh institusi formal. Tabel di bawah adalah pemahaman mengenai fokus utama pemebelajaran dan pengajaran. Tidak semua disadari oleh masyarakat adat Ammatoa, namun pandangan Harefa (2001: 63-64) berikut cukup mampu memberikan gambaran proses dan hasil yang diharapkan oleh masyarakat adat Ammatoa dari proses pengajaran yang difasilitasi oleh institusi formal.

Berdasarkan pemahaman bahwa ilmu pengetahuan seharusnya bisa disajikan oleh sekolah formal, maka sebenarnya masyarakat adat Ammatoa telah mampu memposisikan identitas mereka sebagai masyarakat adat dan posisi Negara sebagai pengatur hajat hidup warga Negara secara keseluruhan tanpa pengecualian, termasuk masyarakat adat Ammatoa.

Kedua, pengalaman. Tahappengetahuan yang telah dijelaskan sebelumnya adalah kemampuan untuk memilih persamaan dan perbedaan di antara keduanya. Sedangkan tahap pengalaman ini adalah tahap yang memainkan kesadaran untuk memilah dan memutuskan apakah mereka akan beralih ke budaya yang baru, mempertahankan dengan tegas budayanya, mengeloborasi budaya mereka atau bertransformasi.

Posisi masyarakat adat Ammatoa dengan Negara adalah posisi yang membu- 
tuhkan keseimbangan agar tidak ada hak dan tanggung jawab masing-masing yang ditindas. Meskipun, Negara telah melakukan "pemaksaan" di awal. Namun, masyarakat adat Ammatoa berusaha menciptakan ruang evaluatif. Pertama adalah dengan berdialog bersama, yang akhirnya membuat mereka memindahkan batas penanda antara ilalang embayya dengan ipantarang embayya. Selanjutnya, ruang evaluatif ini diciptakan dengan melakukan resistensi latent (sembunyi-sembunyi).

Sejak awal didirikannya SD 351 di kawasan adat, salah satu yang sering dikeluhkan oleh guru-guru adalah banyaknya siswa yang sering membolos sekolah, hingga melewati batas toleransi kehadiran yang ditetapkan sekolah. Faktor ekonomi tentu tidak cukup untuk merasionalkan keadaan ini.

Masyarakat adat Ammatoa adalah masyarakat yang terbiasa untuk mengikutkan anak-anaknya untuk bekerja baik untuk bertani, hingga pekerjaan-pekerjaan lain yang membawa mereka keluar kecamatan. Bagi mereka, anak-anak yang pantas untuk menikah adalah anak-anak yang secara fisik bisa mandiri. Bekerja adalah salah satu cara untuk memandirikan anak-anak mereka. Namun untuk menarik kesimpulan bahwa mereka dididik untuk menikah sejak dini adalah kesimpulan yang terlalu cepat. Hal penting yang lain adalah sejak kecil anakanak di dalam kawasan adat telah diajarkan bahwa bekerja adalah bagian manusiawi dari kehidupan mereka.

Rasionalitas ini yang tetap dihidupkan dalam kehidupan sehari-hari. Banyaknya anak-anak yang sering membolos sekolah bukan karena semata-mata keinginan mereka untuk tidak belajar, melainkan karena mereka tetap menjalankan kebiasaan mereka seharihari. Mulai dari bekerja hingga melaksanakan ritual. Jika ada ritual-ritual yang dilaksanakan, maka anak-anak yang mengenakan seragam merah putih, dilarang berlalu lalang. Mereka bahkan lebih sering memutuskan untuk tidak berangkat ke sekolah. Hal ini yang kemudian memunculkan kembali ruang dialog bersama oleh pihak sekolah dengan Ammatoa dan masyarakatnya. Melalui ruang dialog (a'borong) ini, Ammatoa meminta secara langsung agar seragam mereka diganti menjadi putih hitam.

Ketiga, komponen lintas budaya masyarakat adat Ammatoa adalah kemampuan. Kemampuan ini yang menunjukkan kemampuan menegosiasi identitas masyarakat adat Ammatoa terhadap budaya lain di luar mereka. Upaya yang dilakukan oleh masyarakat adat Ammatoa adalah mengelaborasi kebiasaan mereka agar kebiasaan ini juga dihormati oleh pemerintah yang telah mendekatkan sekolah formal secara fisik dengan lingkungan mereka.

Suara Ammatoa sebagai pemimpin juga adalah suara masyarakat adat Ammatoa secara kultural, meskipun secara personal belum tentu. Sehingga, secara kultural ketika Ammatoa memutuskan untuk memindahkan gerbang secara langsung mereka telah menerima sistem pendidikan formal ini, namun belum maksimal. Hal ini merupakan simbol resistensi latent (sembunyi-sembunyi) 
yang mereka lakukan. Baru setelah Ammatoa meminta untuk mengganti warna seragam sebagai bentuk elaborasi cara kerja keduanya (masyarakat adat Ammatoa dan pemerintah), maka perlawanan mereka telah manifest (terbuka atau terang-terangan). Masyarakat adat Ammatoa telah memasukkan ciri khas simbolik mereka untuk merubah peraturan sekolah pada umumnya.

Dalam konteks negosiasi identitas kebudayaan, berhasil memainkan ciri khas (salience) mereka ke dalam kebiasaankebiasaan di luar mereka. Selain itu, kemampuan mereka menganalisis diri mereka dengan tetap melakukan "perlawanan halus" adalah upaya untuk melibatkan nilai isi (value content) dari kebiasaan sehari-hari mereka. Hal ini bisa dilihat dari komponen pengetahuan di atas.

Jika dalam konteks teori, negosiasi akan menghasilkan keberdayaan atau bahkan kemarjinalan, maka dalam masyarakat adat Ammatoa sebenarnya mereka telah berdaya secara komunal, bahkan sebelum mereka melakukan negosiasi dengan institusi pendidikan formal.

\section{SIMPULAN}

Melihat masyarakat adat Ammatoa secara utuh perlu dilakukan dari sudut pandang relatifisme kebudayaan. Mereka telah tumbuh dan berkembang dengan sejarah mereka masing-masing dan pengaruh lingkungan serta internal mereka yang kompleks.

Sejak dulu, masyarakat adat Ammatoa tidak tertutup, melainkan selektif. Hal ini yang membuat mereka akan mudah bertransformasi. Begitupun dalam upaya mereka untuk bernegosiasi dengan pendidikan konvensional. Hal ini adalah bagian dari praktik berpolitik mereka. bagaimanapun, proses negosiasi adalah upaya adaptif masyarakat adat Ammatoa terhadap faktor-faktor eksternal yang memungkinkan terjadinya benturan antar budaya. Benturan ini bisa berakibat macammacam, salah satunya bisa berakibat pada eksistensi mereka sebagai masyarakat adat.

\section{DAFTAR PUSTAKA}

(Paper)

[1] Erawati, Erni. 2015. Pola Permukiman Tradisional Kajang. Kapata Arkeologi, Vol 12 No 2, November 2016. Hal: 147-162.

[2] Hijjang, Pawennari. 2005. Pasang Dan Kepemimpinan Ammatoa: Memahami Kembali Sistem Kepemimpinan Tradisional Masyarakat Adat Dalam Pengelolaan Sumberdaya Hutan Di Kajang Sulawesi Selatan. Antropologi Indonesia Vol,29, No,3, 2005: 255-268.

[3] Maarif, Syamsul. 2014, "Being A Muslim In Animistic Ways", Al-Jami'ah: Journal Of Islamic Studies Vol, 52, No, 1 (2014), Hal: 149-174.

[4] Syarif, E., Fatchan, A., Sumarmi., Astina, I. K., 2016, Tradition Of "Pasang Ri Kajang" In Ther Forests Of Managing In System Mores Of "Ammatoa" At District Bulukumba South Sulawesi, Indonesia, Mediteranean Journal of Social Sciences, Vl 7 No 6, 325-332. 


\section{(Buku)}

[5] Atkinson, Robert. 1995. The Gift Of Stories: Practical And Spiritual Applications Of Autobiography, Life Stories, And Personal Mythmaking. Westport, Conecticut, London: Bergin \& Garvey.

[6] Fritjof, Capra. 2017. The Hidden Connection: Strategi Sistematis Melawan Kapitalisme Baru. Yogyakarta: Jalasutra.

[7] Freire, Paulo. 2007. Politik Pendidikan: Kebudayaan, Keuasaan, Dan Pembebasan. Yogyakarta: Pustaka Pelajar.
[8] Harefa, Andrias. 2001. Menjadi Manusia Pembelajar. Jakarta: Pt Kompas Media Nusantara.

[9] Littlejohn, Stephen. W., dan Foss, Karen. A. 2014. Teori Komunikasi: Theories Of Human Communication. Jakarta: Salemba Humanika.

[10] Tika, Z., Embas, M., Kasim, M., Rosdiana. 2015. Ammatoa, Sulawesi Selatan: Lembaga Kajian \& Penulisan Sejarah Budaya Sulawesi Selatan. 
96 Komunikasi, Vol. XIII No. 01, Maret 2019: 83-96 